DOROTA MURZYN

Uniwersytet Pedagogiczny, Kraków, Polska

\title{
Wykorzystanie funduszy strukturalnych UE. w przedsiębiorstwach Małopolski jako czynnik rozwoju gospodarki opartej na wiedzy i innowacji
}

\author{
The Use of EU Structural Funds in Companies of Małopolska \\ region as a Factor in the Development of an Economy Based \\ on Knowledge and Innovation
}

\begin{abstract}
Streszczenie: Celem artykułu jest analiza wykorzystania funduszy strukturalnych UE przez małopolskie przedsiębiorstwa w kontekście budowania gospodarki opartej na wiedzy i innowacji. Przedsiębiorstwa są jednym z głównych aktorów budowania gospodarki opartej na wiedzy i innowacji. Należą one także do najważniejszych beneficjentów funduszy unijnych. Rodzi się zatem pytanie, jak wykorzystywane są te środki, czy i na ile przyczyniają się one do budowania gospodarki opartej na wiedzy i innowacji, a na ile służą zaspokajaniu jedynie bieżących potrzeb. Fundusze polityki spójności alokowane są regionalnie. W celu przeprowadzenia analizy wykorzystania tych środków przez przedsiębiorstwa z Małopolski, przeprowadzono badania, przede wszystkim w oparciu o bazę projektów Krajowego Systemu Informatycznego SIMIK 07-13 (stan na dzień 30.09.2012).

Bez modernizacji przemysłu nie jest możliwe takie nadrobienie zaległości rozwojowych, aby zapewnić spójność z regionami Unii Europejskiej. Znaczne środki kierowane są zatem na ten cel w ramach unijnej polityki spójności. Polska jest obecnie jej największym beneficjentem, a priorytetem w alokacji środków europejskich na rozwój konkurencyjnej gospodarki opartej na wiedzy jest obszar przedsiębiorczości.

Zdecydowana większość projektów realizowanych przez małopolskie przedsiębiorstwa przy wsparciu z funduszy UE to projekty innowacyjne. Ilościowo jednak przeważają projekty o mniejszym potencjale w tym zakresie, np. projekty służące wzrostowi działalności eksportowej. Niepokój może budzić fakt, że jedynie niewielka liczba projektów służyć ma wsparciu wdrożenia wyników prac $\mathrm{B}+\mathrm{R}$, wsparciu w zakresie rozwoju działalności $\mathrm{B}+\mathrm{R}$ w przedsiębiorstwach, czy współpracy środowiska naukowobadawczego z przedsiębiorcami.
\end{abstract}

Abstract: This article aims to analyze the use of EU structural funds by the enterprises from Małopolska region in the context of building an economy based on knowledge and innovation. Enterprises are one of the main actors to build an economy based on knowledge and innovation. These are also the main beneficiaries of EU funds. This raises the question of how these funds are used, whether and to what 
extent they contribute to building an economy based on knowledge and innovation, and to what extent they aimed at satisfying only the current needs. Cohesion policy funds are allocated regionally. In order to analyze the use of these funds by the company from Małopolska region, research has been made, primarily based on the database of the National Information System projects SIMIK 07-13 (as of 30.09.2012).

Without modernization of industry it is not possible to achieve cohesion with the regions of the European Union. Considerable resources are therefore directed to this purpose in the framework of EU cohesion policy. Poland is currently the biggest beneficiary of that policy, with a strong priority in the allocation of European funds for the development of a competitive knowledge-based economy and entrepreneurship.

The vast majority of projects implemented by companies in Małopolska region with the support of EU funding are innovative projects. Quantitatively, however, projects of smaller potential dominate in this area, such as projects to increase exports. What raises concerns is the fact that only a small number of projects are to support the implementation of $R \& D$ results, the development of $R \& D$ activities in enterprises and cooperation between researchers and entrepreneurs.

Słowa kluczowe: gospodarka oparta na wiedzy, polityka spójności, fundusze strukturalne UE, SIMIK

Key words: knowledge-based economy, cohesion policy, EU structural funds, SIMIK

\section{WPROWADZENIE}

Nowoczesny rozwój gospodarczy jest w istotny sposób określony i napędzany przez pojawienie się gospodarki opartej na wiedzy. Akcentuje ona zmiany strukturalne, które mają miejsce w nowoczesnych gospodarkach, a polegają na reorientacji i stopniowym przechodzeniu od gospodarki materiałochłonnej do gospodarki opartej na informacji i wiedzy. Dostęp do wiedzy jest powszechnie uznawany za kluczowy warunek dla działań innowacyjnych w nowoczesnej gospodarce przestrzennej. W konsekwencji, tworzenie i rozpowszechnianie wiedzy może działać jako kluczowy czynnik sukcesu w rozwoju regionalnym i krajowym. Do głównych aktorów budowania gospodarki opartej na wiedzy należy zaliczyć: rząd wraz z jego agendami, władze samorządowe - regionalne i lokalne, szkoły wyższe i instytuty badawcze oraz przedsiębiorców.

Budowa gospodarki opartej na wiedzy wymaga znacznego udziału nakładów w PKB na finansowanie badań i rozwoju, infrastruktury, a także usług informatycznych. Niezbędne jest zapewnienie wysokiego poziomu innowacyjności przemysłu, między innymi przez rozwój wysokozaawansowanych, konkurencyjnych technologii. Takie działania wymagają znaczących zasobów finansowych. W Unii Europejskiej strukturalny podział finansowania w celu wsparcia budowy gospodarki opartej na wiedzy i innowacji znacznie wzrósł wraz z rozpoczęciem realizacji Strategii Lizbońskiej, a następnie strategii Europa 2020. Priorytety obu tych strategii są częściowo zgodne: najważniejsze obszary to konkurencyjność, budowanie gospodarki opartej na wiedzy, ochrona środowiska, wysokie zatrudnienie i spójność społeczna. Nowa strategia położyła jednak jeszcze większy nacisk na wzmocnienie społeczeństwa cyfrowego, rozwój badań i innowacji, racjonalnego wykorzystania zasobów naturalnych, 
rozwijania przedsiębiorczości i konkurencyjności, przy jednoczesnym zachowaniu celów wzrostu zatrudnienia i ograniczenia ubóstwa.

Realizacji celów Strategii Lizbońskiej, a obecnie strategii Europa 2020, podporządkowane są środki polityki spójności UE. W latach 2007-2013 dzięki instrumentom tej polityki na działalność badawczo-rozwojową i innowacje, w tym włączanie do głównego nurtu działań innowacyjnych i działalności eksperymentalnej, przeznaczono środki w wysokości około 86,4 mld EUR (prawie 25\% całego budżetu). Polska jest największym beneficjentem polityki spójności w obecnym okresie programowania. W najważniejszym dokumencie strategicznym dla tej polityki (Narodowe Strategiczne Ramy Odniesienia), „tworzenie warunków dla wzrostu konkurencyjności gospodarki polskiej opartej na wiedzy i przedsiębiorczości” zostało określone jako główny cel strategiczny.

Zdecydowanym priorytetem w alokacji środków europejskich na rozwój konkurencyjnej gospodarki opartej na wiedzy jest w Polsce obszar przedsiębiorczości. Przedsiębiorstwa stanowią ważną grupę beneficjentów funduszy strukturalnych od początku realizacji polityki spójności w Polsce. Celem artykułu jest analiza wykorzystania funduszy strukturalnych UE przez małopolskie przedsiębiorstwa w kontekście budowania gospodarki opartej na wiedzy $\mathrm{i}$ innowacji. W tym celu przeprowadzono badania, przede wszystkim w oparciu o bazę projektów Krajowego Systemu Informatycznego SIMIK 07-13 (stan na dzień 30.09.2012).

\section{StAn ROZWOJU GOSPODARKI OPARTEJ NA WIEDZY I INNOWACJI W MAŁOPOLSCE}

Pojęcie gospodarki opartej na wiedzy uznaje zmiany strukturalne, które mają miejsce w nowoczesnych gospodarkach. W przeszłości, wzrost był w dużej mierze oparty na kompetencjach w zakresie gospodarki opartej na materiałach - to jest na branżach produkcyjnych. Teraz struktura gospodarki opiera się na bardziej niematerialnych czynnikach związanych z wiedzą (Molle 2011: 171). Wiedza jest pojęciem wielowymiarowym, a tworzenie wiedzy jest procesem złożonym (Arrow 1994). Efektywna dystrybucja wiedzy poprzez sieci formalnych i nieformalnych powiązań jest niezbędna dla osiągnięcia dobrych wyników gospodarczych (Nelson 1993; Lundvall 1992). Literatura empiryczna na temat interakcji pomiędzy technologią a wzrostem jest bogata (Verspagen 1994; Link, Siegel 2003). Teoria wiąże rozwój zasobów wiedzy z innowacjami i wzrostem gospodarczym (Lever 2002). Konkurencyjność gospodarki jest uwarunkowana jej innowacyjnością. Innowacje są wynikiem wiedzy. Poziom innowacyjności zależy nie tylko od postępu nowych technologii, ale również od wiedzy i umiejętności, kapitału ludzkiego (Klamut 2011). Również specyfika kluczowej relacji między wiedzą a innowacją oraz jej centralne znaczenie dla wydajności firmy zostały zbadane (Howells 2000).

Pozycja regionu w stosunku do wiedzy i technologii określana jest przez trzy czynniki (Wintjes, Hollanders 2010: 3):

- dostęp do wiedzy,

- zdolność do absorpcji wiedzy,

- zdolność do dyfuzji wiedzy i technologii. 
Wintjes i Hollander opracowali typologię regionów Unii Europejskiej, wyróżniając siedem różnych typów w zależności od relacji między postępem technicznym a rozwojem.

Tab. 1. Klasyfikacja regionów ze względu na dostępność, absorpcję i dyfuzję wiedzy

\begin{tabular}{|l|l|l|l|}
\hline & \multicolumn{3}{|c|}{ Dostępność } \\
\hline & \multicolumn{1}{|c|}{ Niska } & \multicolumn{1}{|c|}{ Średnia } & \multicolumn{1}{|c|}{ Wysoka } \\
\hline $\begin{array}{l}\text { Absorpcja: niska } \\
\text { Dyfuzja: niska }\end{array}$ & $\begin{array}{l}\text { Tradycyjne } \\
\text { południowe } \\
\text { regiony UE }\end{array}$ & $\begin{array}{l}\text { Wykwalifikowane przemy- } \\
\text { słowe regiony wschodniej } \\
\text { UE }\end{array}$ & \\
\hline $\begin{array}{l}\text { Absorpcja: średnia } \\
\text { Dyfuzja: średnia }\end{array}$ & & $\begin{array}{l}\text { Regiony absorbujące wie- } \\
\text { dzę; } \\
\text { Wykwalifikowane technolo- } \\
\text { giczne regiony }\end{array}$ & $\begin{array}{l}\text { Publiczne ośrodki } \\
\text { wiedzy }\end{array}$ \\
\hline $\begin{array}{l}\text { Absorpcja: wysoka } \\
\text { Dyfuzja: średnia }\end{array}$ & & $\begin{array}{l}\text { Metropolitalne regiony usług } \\
\text { wykorzystujących wiedzę }\end{array}$ & $\begin{array}{l}\text { Regiony wysoko } \\
\text { zaawansowane } \\
\text { technologicznie }\end{array}$ \\
\hline $\begin{array}{l}\text { Absorpcja: wysoka } \\
\text { Dyfuzja: wysoka }\end{array}$ & & & \\
\hline
\end{tabular}

Źródło: Wintjes, Hollanders 2010, s. 16

Większość regionów Polski, w tym Małopolska, zostało zakwalifikowanych jako „wykwalifikowane przemysłowe regiony wschodniej UE”, posiadające średnią dostępność do wiedzy oraz niską jej absorpcję i dyfuzję. Jedynie mazowieckie zostało zakwalifikowane do „publicznych ośrodków wiedzy” z wysoką dostępnością wiedzy i średnim poziomem jej absorpcji i dyfuzji. Sytuację regionów w zakresie innowacji obrazuje Regionalny Wskaźnik Innowacyjności (Hollanders i in. 2009). Klasyfikuje on regiony do pięciu kategorii, od regionów o niskim do wysokiego poziomu innowacyjności. Regiony Polski klasyfikowane są na końcu tego zestawienia.

Statystyki potwierdzają znaczne dysproporcje między poszczególnymi państwami członkowskimi i regionami UE w dziedzinie innowacji i działalności badawczo-rozwojowej. Z uwagi na dostępność danych statystycznych na poziomie regionalnym, najczęściej analizowanym wskaźnikiem prezentującym miejsce regionu w budowaniu gospodarki opartej na wiedzy i innowacji jest wielkość (i struktura) nakładów na działalność badawczo-rozwojową. W Polsce wskaźnik ten przyjmuje alarmująco niski poziom, zarówno w wielkościach bezwzględnych, jak i w relacji do PKB czy liczby mieszkańców. Od 2002 r. wskaźnik udziału nakładów na B + R w PKB kształtuje się na poziomie ok. 0,56\%, co stanowi 30\% średniej unijnej. Występują przy tym istotne i trwałe różnice $\mathrm{w}$ potencjale innowacyjnym poszczególnych województw - ponad 50\% wydatków na B+R koncentruje się w dwóch polskich województwach: mazowieckim i małopolskim, podczas gdy nakłady ponoszone w województwach świętokrzyskim, opolskim, podlaskim, lubuskim, warmińsko-mazurskim czy zachodniopomorskim mają charakter marginalny (ryc. 1). 


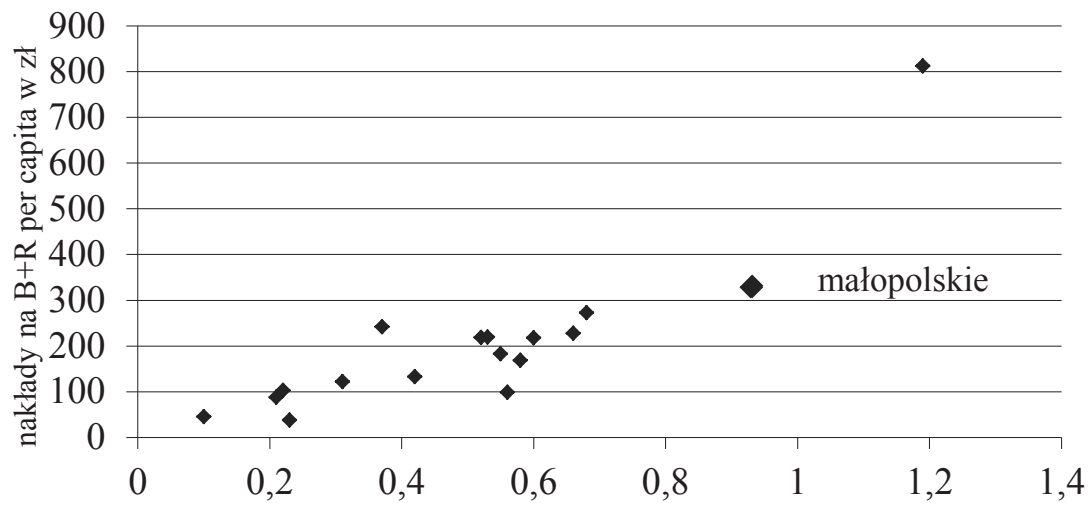

nakłady na $\mathrm{B}+\mathrm{R}$ jako \% PKB

Ryc. 1. Nakłady na B+R w województwach Polski w 2010 r.

Źródło: opracowanie własne na podstawie danych GUS, Regiony Polski, Główny Urząd Statystyczny, Warszawa 2012, s. 24

Województwo małopolskie prezentuje się w tym zestawieniu bardzo dobrze, jest drugim pod względem wyników regionem w Polsce. Jeśli jednak porównamy potencjał Małopolski z regonami Unii Europejskiej, obraz rysuje się już nieco inaczej (ryc. 2).

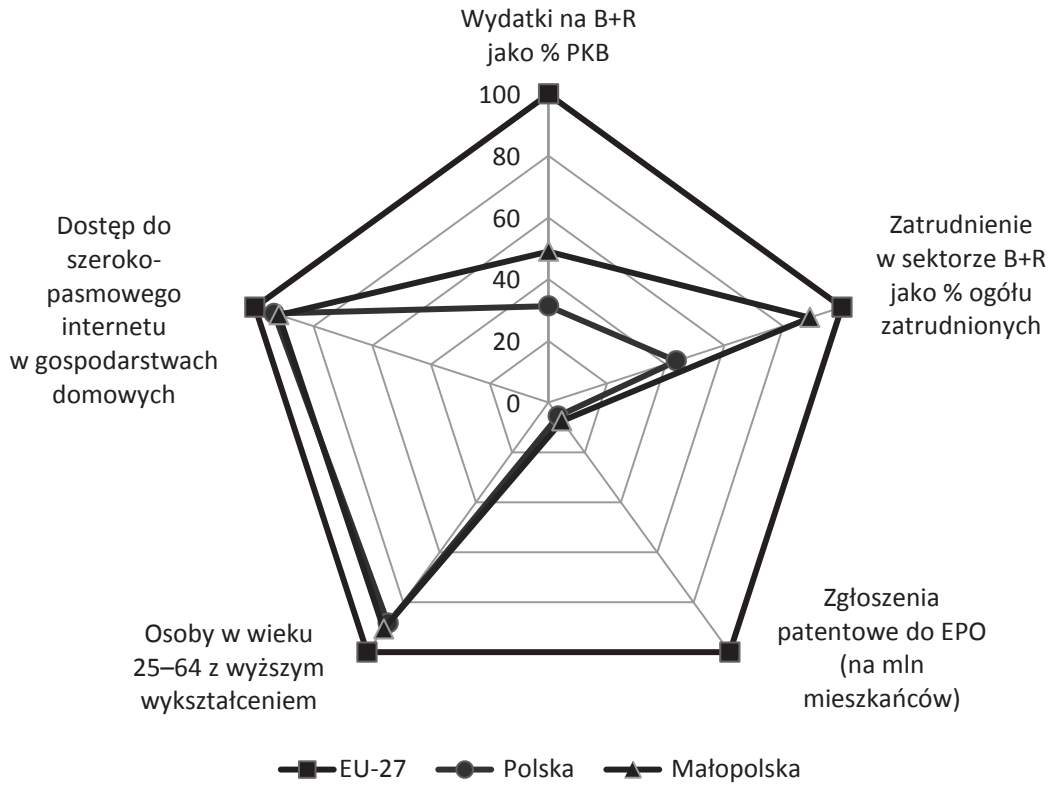

Ryc. 2. Poziom konwergencji Polski i Małopolski w obszarze konkurencyjności (EU-27=100\%)

Źródło: opracowanie własne na podstawie danych Eurostatu (dane z lat 2008-2010, najbardziej aktualne, dostępne na poziomie regionalnym na dzień 30.11.2012) 
Małopolska, choć wciąż wypada lepiej niż średnia krajowa, to w porównaniu z regionami UE większość jej wskaźników konkurencyjności osiąga poziom niższy od średniej unijnej. Największe dysproporcje widoczne są w przypadku liczby zgłoszeń patentowych do EPO w przeliczeniu na milion mieszkańców. W 2008 roku wskaźnik ten kształtował się w Unii Europejskiej na poziomie 111,58, podczas gdy w Polsce osiągał zaledwie 6,01.

Wiedza i innowacje mają ogromne znaczenie w kreowaniu procesów rozwojowych. Umiejętność tworzenia i wykorzystywania wiedzy dla produkcji i przenoszenia jej do procesów innowacyjnych stały się głównym czynnikiem konkurencyjności rynkowej. Zgodnie $\mathrm{z}$ modelem potrójnej helisy przedsiębiorstwa są jednym z trzech aktorów (obok administracji i uniwersytetów), których działania przekładają się na funkcjonowanie regionu. Platformą partnerskiej współpracy między tymi trzema środowiskami: władzami regionalnymi, środowiskiem naukowym i biznesem, mają być między innymi Regionalne Strategie Innowacji. Podmioty gospodarcze zajmujące się implementowaniem nowoczesnych rozwiązań w działalności przemysłowej stanowią jeden z istotnych elementów regionalnego systemu innowacji (Markowski 2000). Małopolska opracowała taką strategię w 2005 roku, a w 2008 roku dokonano jej aktualizacji. RSI to podstawowe narzędzie kształtowania polityki innowacyjnej na poziomie regionu. Celem RSI jest budowanie przewagi konkurencyjnej regionów i wzmocnienie ich zdolności wykorzystania wiedzy i innowacji, a także podnoszenie konkurencyjności MŚP poprzez wprowadzenie nowych technologii.

Działania przedsiębiorstw w obszarze innowacyjności gospodarki i jej powiązania z regionalnymi systemami innowacji wspierane mogą być poprzez realizację celów polityki spójności Unii Europejskiej. Fundusze strukturalne UE stanowią podstawowe źródło finansowania celów Regionalnych Strategii Innowacji.

\section{WYKORZYSTANIE FUNDUSZY STRUKTURALNYCH UE \\ DLA BUDOWANIA GOSPODARKI OPARTEJ NA WIEDZY I INNOWACJI \\ PRZEZ MAŁOPOLSKIE PRZEDSIĘBIORSTWA}

Małopolskie przedsiębiorstwa aktywnie wykorzystują szansę rozwoju, jaką stwarzają fundusze Unii Europejskiej (Murzyn 2012). Czy jednak, i na ile, inwestycje przez nie realizowane przyczyniają się do budowania gospodarki opartej na wiedzy i innowacji?

Przedsiębiorstwa w województwie małopolskim są największym beneficjentem funduszy strukturalnych UE, biorąc pod uwagę zarówno liczbę realizowanych projektów, jak i ich wartość (ryc. 4 i 5). Do końca września 2012 r. przedsiębiorstwa i przedsiębiorcy podpisali łącznie 4439 umów (z tego najwięcej - 1545 w ramach Małopolskiego Regionalnego Programu Operacyjnego) na kwotę dofinansowania ze środków UE sięgającą blisko 4,5 mld zł. Porównując liczbę złożonych wniosków do alokacji dostępnej w ramach poszczególnych programów i działań, wyraźnie można zaobserwować, że programy przeznaczone dla przedsiębiorstw budziły największe zainteresowanie. 


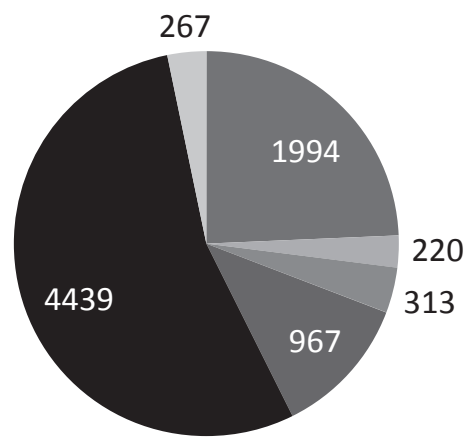

- jst

administracja publiczna

- jednostki naukowe i uczelnie wyższe

fundacje i

stowarzyszenia

przedsiębiorstwa

inne

Ryc. 3. Liczba projektów realizowanych przez poszczególne kategorie beneficjentów w Małopolsce Źródło: opracowanie własne na podstawie bazy projektów SIMIK 2007-2013, stan na 30.09.2012

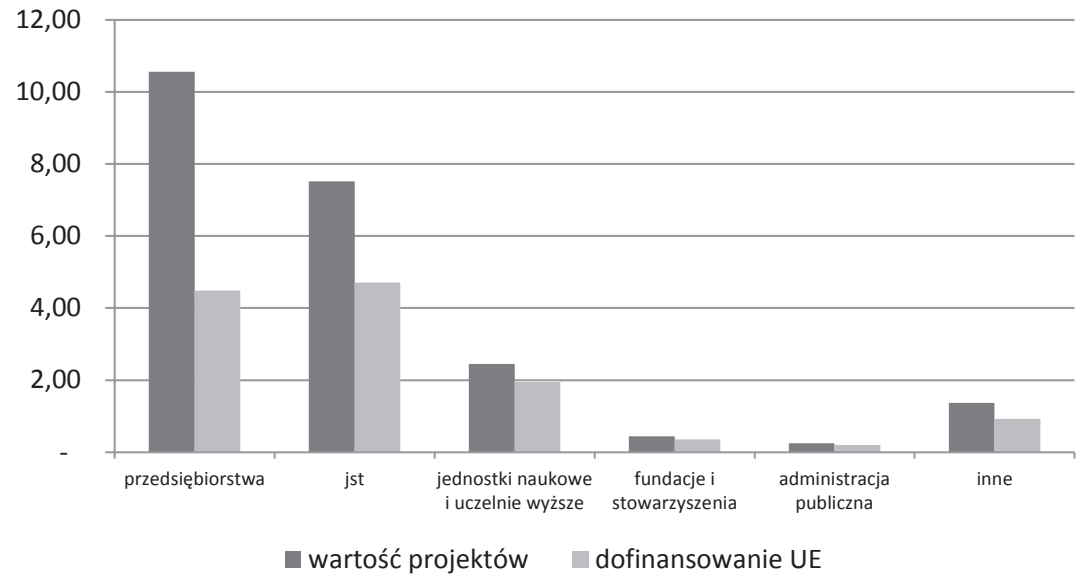

Ryc. 4. Wartość dofinansowania w podziale na kategorie beneficjentów (mld zł)

Źródło: opracowanie własne na podstawie bazy projektów SIMIK 2007-2013, stan na 30.09.2012

Najwięcej projektów realizują najmniejsze przedsiębiorstwa. Mikro, małe i średnie przedsiębiorstwa realizowały 93\% wszystkich projektów przedsiębiorstw (ryc. 4). Pod względem wartości uzyskanego dofinansowania, wyraźnie rysuje się przewaga dużych przedsiębiorstw. Wyjaśnia to strukturę ilościową i wartościową projektów. MŚP najczęściej sięgają po środki w ramach MRPO i POKL i realizują mniejsze projekty pod względem wartości. 
Liczba projektów

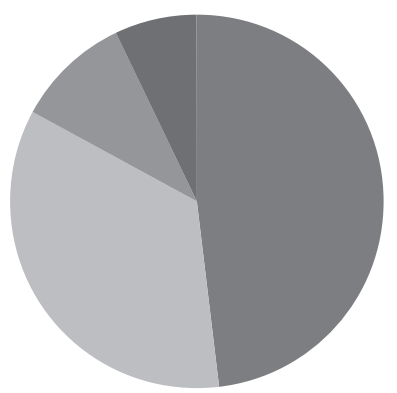

mikro małe średnie aduże
Wartość dofinansowania

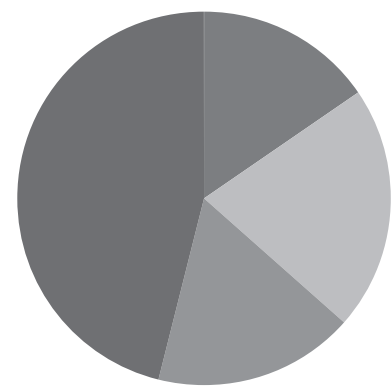

mikro małe średnie d duże

Ryc. 5. Liczba projektów realizowanych przez poszczególne kategorie przedsiębiorstw oraz wartość uzyskanego przez nie dofinansowania z UE

Źródło: opracowanie własne na podstawie bazy projektów SIMIK 2007-2013, stan na 30.09.2012

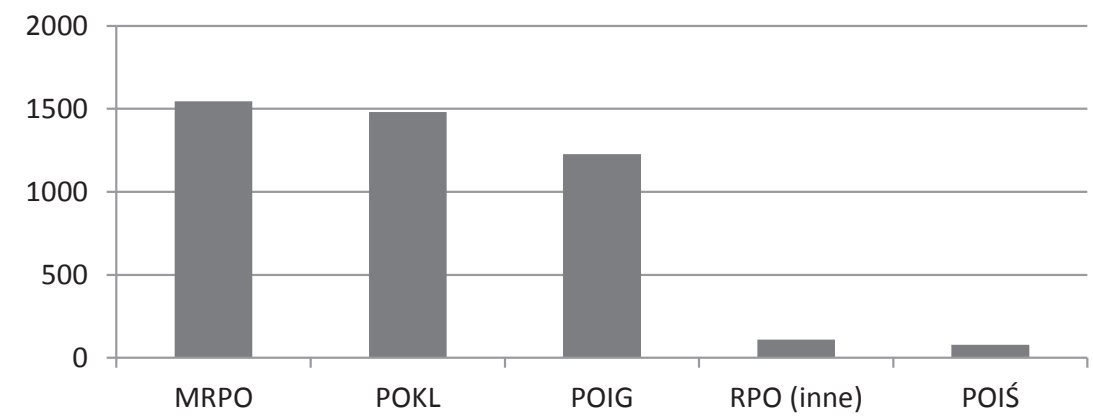

Ryc. 6. Liczba projektów realizowanych przez małopolskie przedsiębiorstwa w podziale na programy operacyjne

Źródło: opracowanie własne na podstawie bazy projektów SIMIK 2007-2013, stan na 30.09.2012

Przedsiębiorstwa często wielokrotnie korzystają z dostępnego wsparcia publicznego, zatem ilość projektów nie jest równoznaczna z ilością przedsiębiorstw, które skorzystały ze wsparcia. Szereg projektów nie ogranicza się do terenu zdefiniowanego lokalizacją głównej siedziby beneficjenta, lecz realizowany jest również na terenie sąsiednich województw. Licząc tak realizowane projekty uzyskujemy dodatkowe informacje $\mathrm{w}$ zakresie wymiaru przestrzennego i oddziaływania beneficjentów zlokalizowanych w poszczególnych jednostkach podziału terytorialnego na inne regiony. Pośrednio świadczy to o sile tych podmiotów. Małopolskie przedsiębiorstwa pozyskują środki nie tylko z programów krajowych i MRPO, ale także z innych programów regionalnych ( $w$ tym najwięcej z RPO województwa śląskiego i podkarpackiego). Strukturę projektów według poszczególnych programów operacyjnych prezentują ryc. 5 i 6 . 
W celu zbadania wpływu inwestycji realizowanych przez małopolskie przedsiębiorstwa, współfinansowanych ze środków funduszy strukturalnych na rozwój gospodarki opartej na wiedzy i innowacji, warto przyjrzeć się rodzajom realizowanych projektów. Ryciny 7 i 8 przedstawiają programy, z których korzystają przedsiębiorstwa z podziałem na działania, czyli rodzaje projektów. Zostały one zestawione z Regionalną Strategią Innowacji Województwa Małopolskiego, gdzie wskazano źródła finansowania działalności innowacyjnej.

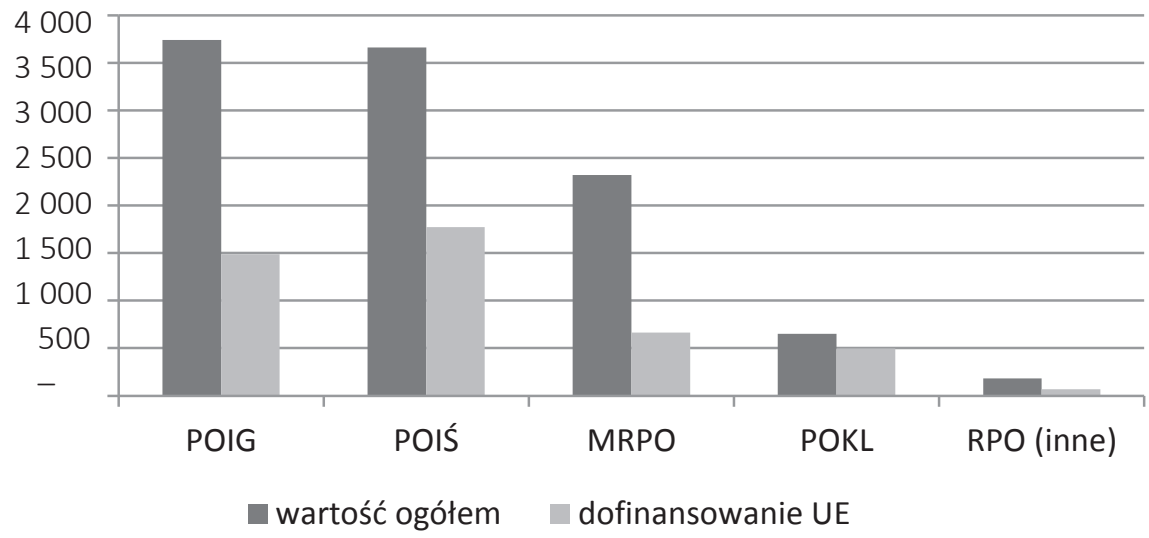

Ryc. 7. Wartość projektów realizowanych przez małopolskie przedsiębiorstwa w podziale na programy operacyjne ( $\mathrm{mln} \mathrm{z})$

Źródło: opracowanie własne na podstawie bazy projektów SIMIK 2007-2013, stan na 30.09.2012

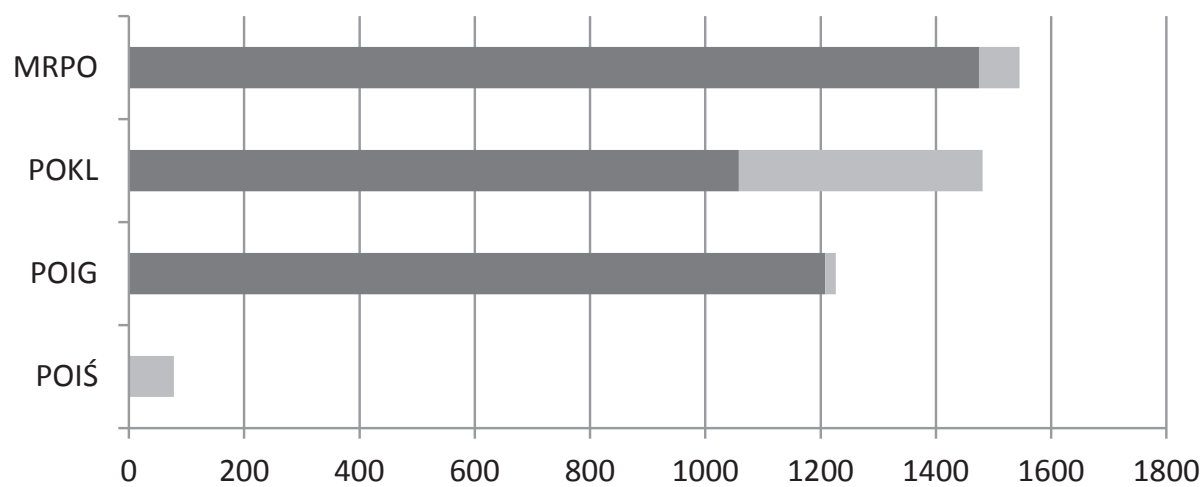

—źródła finansowania działalności innowacyjnej wg RSI —inne

Ryc. 8. Programy, z których korzystają przedsiębiorstwa w Małopolsce (liczba projektów z danych programów, z podziałem na działania)

Źródło: opracowanie własne na podstawie bazy projektów SIMIK 2007-2013, stan na 30.09.2012 
Zdecydowana większość projektów realizowanych przez małopolskie przedsiębiorstwa przy wsparciu funduszy UE to projekty innowacyjne. Nieco inaczej wygląda sytuacja jeśli weźmiemy pod uwagę wartość projektów czy wartość dofinansowania z unijnej polityki spójności. Pod względem wartości dofinansowania najwięcej środków pozyskały przedsiębiorstwa realizujące projekty transportowe i środowiskowe (w ramach programu Infrastruktura i Środowisko).

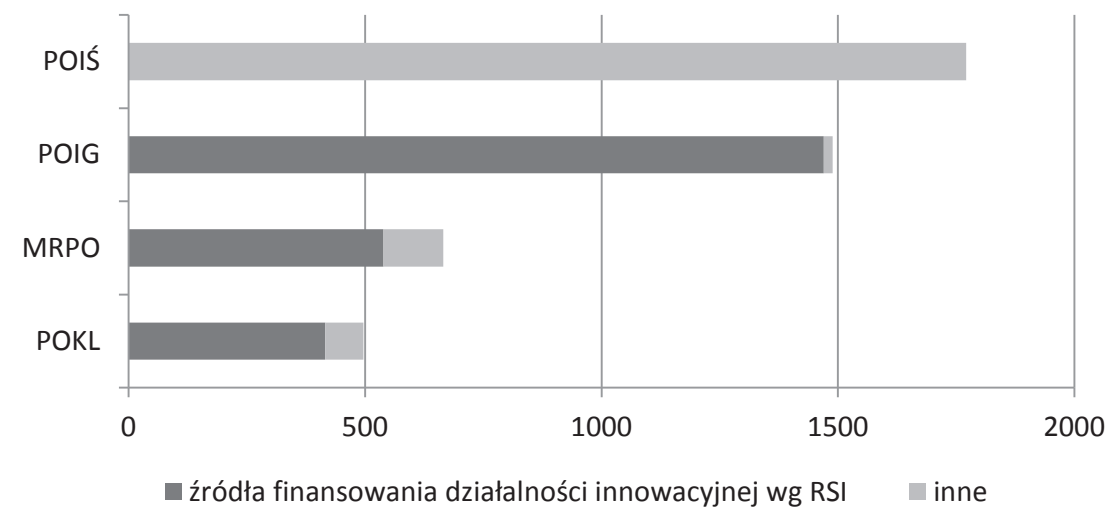

Ryc. 9. Programy, z których korzystają przedsiębiorstwa w Małopolsce

(wartość dofinansowania z UE projektów z danych programów w mln zł, z podziałem na działania)

Źródło: opracowanie własne na podstawie bazy projektów SIMIK 2007-2013, stan na 30.09.2012

Najwięcej projektów realizowanych jest w ramach Małopolskiego Regionalnego Programu Operacyjnego współfinansowanego z Europejskiego Funduszu Rozwoju Regionalnego. Działanie 2.1 Rozwój i podniesienie konkurencyjności przedsiębiorstw jest największym źródłem wsparcia dla rozwoju małopolskich przedsiębiorstw. Jego celem jest podniesienie konkurencyjności sektora MŚP poprzez bezpośrednią pomoc finansową oraz stworzenie warunków dla rozwoju przedsiębiorczości dzięki zwiększonej dostępności do instrumentów finansowania działalności gospodarczej w postaci pożyczek i poręczeń, promowanie kooperacji i tworzenia struktur klastrowych, wsparcie dla instytucji otoczenia biznesu.

Kolejnym programem, z którego w dużym stopniu korzystają małopolskie przedsiębiorstwa i źródłem finansowania działalności innowacyjnej jest Program Operacyjny Innowacyjna Gospodarka. Najwięcej projektów realizowanych jest w ramach działania 6.1 Paszport do eksportu, którego celem jest zwiększenie wielkości polskiego eksportu i sprzedaży na Jednolitym Rynku Europejskim oraz zwiększenie liczby firm prowadzących działalność eksportową. Bardzo dużo projektów realizowanych jest także w ramach priorytetu ósmego, a służą one: stymulowaniu rozwoju rynku usług świadczonych w formie elektronicznej (e-usług) przez mikro i małych przedsiębiorców; stymulowaniu tworzenia wspólnych przedsięwzięć biznesowych prowadzonych w formie elektronicznej, typu B2B; stworzeniu możliwości dostarczania szerokopasmowego dostępu do Internetu na obszarach na których prowadzenie tego typu działalności na zasadach rynkowych jest nieopłacalne. Z kolei 
W ramach priorytetu czwartego realizowane są następujące przedsięwzięcia: wsparcie wdrożenia wyników prac $\mathrm{B}+\mathrm{R}$; wsparcie $\mathrm{w}$ zakresie rozwoju działalności $\mathrm{B}+\mathrm{R} \mathrm{w}$ przedsiębiorstwach, w tym przekształcenia przedsiębiorcy w Centrum Badawczo-Rozwojowe, projekty z zakresu opracowania wzoru przemysłowego lub użytkowego i wdrożenia go do produkcji; wsparcie inwestycji w zakresie wdrażania nowych technologii poprzez udzielenie MŚP kredytu technologicznego z możliwością częściowej spłaty ze środków Funduszu Kredytu Technologicznego w formie premii technologicznej; wsparcie nowych inwestycji o wysokim potencjale innowacyjnym; wsparcie inwestycji o dużym znaczeniu dla gospodarki.

Źródłem finansowania działalności innowacyjnej jest także PO Kapitał ludzki. Najwięcej projektów dotyczy podniesienia i dostosowania kwalifikacji i umiejętności osób pracujących do potrzeb regionalnej gospodarki, poprzez specjalistyczne szkolenia, kursy oraz doradztwo w zarządzaniu przedsiębiorstwem. Wiele działań ukierunkowanych jest na rozwój kadr nowoczesnej gospodarki. Celem jest podnoszenie i dostosowanie do wymogów gospodarki opartej na wiedzy kwalifikacji pracowników i przedsiębiorców, poprzez ogólne i specjalistyczne systemy szkoleń doradztwa, studia podyplomowe oraz wzmacnianie potencjału adaptacyjnego przedsiębiorstw poprzez promowanie nowoczesnych rozwiązań w zakresie zarządzania.

Ponadto przedsiębiorstwa z Małopolski realizują projekty z innych programów i działań, współfinansowanych ze środków unijnych, jednak nie są już one wskazywane jako źródła finansowania działalności innowacyjnej. Najwięcej takich projektów (i o najwyższej wartości) wspieranych jest przez Program Operacyjny Infrastruktura i Środowisko.

Jednym z powszechnie stosowanych wskaźników innowacyjności jest liczba uzyskanych patentów. Własność intelektualna w postaci patentów, praw autorskich, znaków towarowych oraz wzorów przemysłowych odgrywa kluczową rolę w procesie innowacji i pozwala czerpać korzyści z twórczej kreatywności zasobów ludzkich (Gierańczyk 2010). Prawa do własności intelektualnej to mechanizm komercjalizacji innowacji oraz tworzenia wartości ekonomicznej. Poprawie efektywności funkcjonowania rynku innowacji i przepływu rozwiązań innowacyjnych, poprzez upowszechnianie stosowania prawa własności intelektualnej, w szczególności poprzez uzyskiwanie ochrony własności przemysłowej, służą inwestycje W ramach działania 5.4 POIG. Wśród projektów finansowanych ze środków funduszy strukturalnych realizowanych przez małopolskie przedsiębiorstwa, 19 projektów dotyczy wsparcia na uzyskanie ochrony własności przemysłowej.

Dla rozwoju innowacyjności kluczową sprawą jest współpraca środowiska naukowobadawczego z przedsiębiorcami. Naturalnym następstwem podejmowanych działań innowacyjnych staje się transfer technologii. Stworzona innowacja ma bowiem wtedy sens i staje się spełniona, gdy zostanie wdrożona do gospodarki i przyczyni się do usprawnienia działania firmy, wzrostu rentowności czy polepszenia życia społeczeństwa. Problemem jest jednak spójność między tym, czego potrzebuje przemysł, a tym, co oferuje nauka. Często oferta naukowa nie spotyka się z zapotrzebowaniem przemysłu, gdyż nie jest nastawiona na konkretne zastosowania. Innym problemem jest odpowiedni marketing rozwiązań naukowych i wynalazków. Wśród źródeł innowacji sektor nauki, a w szczególności uczelnie wyższe, zajmują jednak odległą pozycję. Z danych zarówno Eurostat jak i GUS wynika, że przedsiębiorstwa 
w Polsce stosunkowo rzadziej niż w większości innych krajów UE kooperują w zakresie innowacji ze szkołami wyższymi (ok. 12\% przedsiębiorstw), a wśród źródeł innowacji uczelnie wyższe stanowią zaledwie 1\% (Polska Agencja Rozwoju Przedsiębiorczości 2010). W Małopolsce ok. 33\% przedsiębiorstw współpracowało w zakresie działalności innowacyjnej z innymi podmiotami, przy czym współpraca ta była realizowana w małym stopniu z instytucjami naukowymi, a przede wszystkim z dostawcami, innymi przedsiębiorstwami i klientami (Główny Urząd Statystyczny 2011: 64). W programach finansowanych z funduszy europejskich funkcjonują odpowiednie formy wsparcia badań ukierunkowanych na potrzeby przemysłu i rynku, międzynarodowej ochrony patentowej czy inwestycji w zakup technologii i wdrożenia. Korzystanie z tych programów przyczynia się do uaktywnienia faktycznego transferu technologii. Absorpcja funduszy europejskich w kolejnych okresach proponowania (2004-2006, 2007-2013) może być rozpatrywana jako znaczący impuls sprzyjający tworzącemu się systemowi transferu technologii i komercjalizacji wiedzy. System taki wytwarza się na styku narodowego i regionalnych systemów innowacji (Matusiak, Guliński 2010: 11).

Przedsiębiorstwa mogą współpracować także z innymi podmiotami działającymi w tej samej dziedzinie aktywności gospodarczej w ramach inicjatyw klastrowych. Wśród przedsiębiorstw współpracujących w zakresie działalności innowacyjnej w Małopolsce, ok. 10\% współpracowało w ramach klastrów (Główny Urząd Statystyczny, 2011). Niemniej jednak, zaledwie kilka z nich pozyskało środki z UE na rozwój takiej współpracy.

Europejski Fundusz Rozwoju Regionalnego za pośrednictwem programu Innowacyjna Gospodarka umożliwia inwestowanie w innowacje, w tym zwłaszcza oparte na prowadzeniu prac badawczo-rozwojowych (działanie 1.4 Wsparcie projektów celowych). Projekt celowy składa się z dwóch zasadniczych faz - badawczej, obejmującej badania przemysłowe lub prace rozwojowe oraz części wdrożeniowej. Badania mogą być prowadzone przez przedsiębiorców - samodzielnie lub na zlecenie przedsiębiorców przez jednostki naukowe, bądź innych przedsiębiorców posiadających zdolność do realizacji prac badawczych. Od 2010 r. wprowadzono możliwość realizowania badań przemysłowych lub prac rozwojowych przez przedsiębiorcę wspólnie $\mathrm{z}$ innym przedsiębiorcą lub organizacją badawczą $\mathrm{w}$ ramach tzw. „efektywnej współpracy”. Małopolskie przedsiębiorstwa do końca września 2012 roku realizowały 83 takie projekty na łączną kwotę dofinansowania sięgającą prawie $81,5 \mathrm{mln}$ zł.

Zdecydowanym priorytetem w alokacji środków europejskich na rozwój konkurencyjnej gospodarki opartej na wiedzy w Polsce był w poprzednim okresie programowania i pozostaje obecnie obszar przedsiębiorczości. Stosunkowo duża skala zaangażowanych środków sprawia, że efekty polityki regionalnej są w tym obszarze szczególnie widoczne. Przejawiają się one m.in. we wzroście zatrudnienia, poprawie kwalifikacji pracowników, zmianie struktury pracujących w kierunku zwiększenia udziału specjalności zawodowych związanych z rozwojem gospodarki opartej na wiedzy. Wskazywane przez beneficjentów funduszy europejskich ich oddziaływanie na ulepszenie parku maszynowego i poprawę jakości produkcji przyczynia się do zwiększenia konkurencyjności, czego wyrazem jest wzrost produkcji na rynek krajowy i rynki zagraniczne (Ministerstwo Rozwoju Regionalnego 2010). 
Rozwój przedsiębiorstw i ich efektywne funkcjonowanie jest podstawą wzrostu gospodarczego. Jednym ze środków prowadzących do osiągnięcia tego celu są innowacje. Na sukces innowacyjny wpływa wiele różnorodnych czynników. Wysoki poziom innowacyjności gospodarki spowodowany jest głównie przez działanie mechanizmu konkurencyjnego wśród przedsiębiorstw. Ważnym elementem tego sukcesu jest też interwencjonizm państwowy w postaci odpowiedniej polityki innowacyjnej, wyrażającej się m.in. poprzez nakłady na badania i rozwój. Innowacyjność małych i średnich przedsiębiorstw wspierają także fundusze UE. Innowacje mogą być bowiem podstawowym czynnikiem polaryzacji rozwoju, gdyż dynamiczny rozwój danego regionu zależy od jednoczesnego oddziaływania wielu innowacji powstających i wdrażanych w przedsiębiorstwach (Klamut 2011). W województwie małopolskim 25,4\% aktywnych innowacyjnie przedsiębiorstw przemysłowych i 10,8\% przedsiębiorstw z sektora usług otrzymało w latach 2008-2010 publiczne wsparcie na działalność innowacyjną. Wśród aktywnych innowacyjnie przedsiębiorstw, zarówno przemysłowych, jak i z sektora usług, najwięcej jednostek otrzymało publiczne wsparcie z Unii Europejskiej (Główny Urząd Statystyczny 2011).

\section{Podsumowanie}

Małopolskie przedsiębiorstwa aktywnie uczestniczą w realizacji polityki spójności Unii Europejskiej, są największym beneficjentem funduszy strukturalnych UE spośród podmiotów w regionie, biorąc pod uwagę zarówno liczbę realizowanych projektów, jak i ich wartość. Przy pomocy uzyskanych środków realizują wiele inwestycji, które nie tylko prowadzą do podniesienia ich konkurencyjności na rynku, ale i przyczyniają się do budowania gospodarki opartej na wiedzy i innowacji w regionie.

Zdecydowana większość projektów realizowanych przez małopolskie przedsiębiorstwa przy wsparciu funduszy UE to projekty innowacyjne. Ilościowo jednak przeważają projekty o mniejszym potencjale w tym zakresie, np. projekty służące wzrostowi działalności eksportowej. Niepokój może budzić fakt, że jedynie niewielka liczba projektów służyć ma wsparciu wdrożenia wyników prac $\mathrm{B}+\mathrm{R}$, wsparciu w zakresie rozwoju działalności $\mathrm{B}+\mathrm{R}$ w przedsiębiorstwach czy współpracy środowiska naukowobadawczego z przedsiębiorcami.

\section{Literatura / References}

Arrow, K. (1994). The production and distribution of knowledge. W: G. Silverberg, L. Soete (red.), The economics of growth and technical change. Technologies, nations, agents. Aldershot: Edward Elgar Publishing Company.

Babiak, J. (red.) (2008). Fundusze Europejskie a innowacyjność polskiej gospodarki. Warszawa: Wydawnictwo Studio Emka.

Gierańczyk, W. (2010). Rola własności intelektualnej w budowaniu innowacyjności krajów Unii Europejskiej. Prace Komisji Geografii Przemystu Polskiego Towarzystwa Geograficznego, 16, 76-86. 
Główny Urząd Statystyczny (2011). Działalność innowacyjna przedsiębiorstw w latach 2008-2010. Warszawa.

Główny Urząd Statystyczny (2012). Regiony Polski. Warszawa.

Hollanders, H., Tarantola, S., Loschky, A. (2009). Regional Innovation Scoreboard (RIS) 2009. Inno Metrics.

Howells, J. (2000). Knowledge, innovation and location. W: J.R. Bryson, P.W. Daniels, N. Henry, J. Pollard (red.), Knowledge, space, economy. London-New York: Routledge, Taylor \& Francis Group.

Hryniewicz, J.T. (2010). Gospodarka oparta na wiedzy a globalne procesy geopolityczne. Prace Komisji Geografii Przemystu Polskiego Towarzystwa Geograficznego, 15, 61-68.

Klamut, M. (red.) (2011). Konkurencyjność i spójność w polityce rozwoju Unii Europejskiej. Wrocław: Wydawnictwo Uniwersytetu Ekonomicznego we Wrocławiu.

Komisja Europejska (2010). Europa 2020. Strategia na rzecz inteligentnego i zrównoważonego rozwoju sprzyjającego właczeniu społecznemu. Komunikat Komisji, Bruksela, 03.03.2010, http:// ec.europa.eu/eu2020.

Lever, W.F. (2002). The knowledge base, innovation and urban economic growth. W: Z.J. Acs, H.L.F. De Groot, P. Nijkamp (red.), The emergence of the knowledge economy. A regional perspective. Berlin: Springer-Verlag.

Link, A.N., Siegel, D.S. (2003). Technological change and economic performance, Studies in global competition series. London-New York: Routledge Taylor and Francis Group.

Lundvall, B.A. (red.) (1992). National Systems of Innovations - towards a theory of innovation and interactive learning. London: Pinter.

Markowski, T. (2000). Regionalne systemy innowacji w aspekcie strategii rozwoju regionalnego Polski 2000-2006. W: J. Szlachta (red.), Narodowa Strategia Rozwoju. Biuletyn KPZK PAN, 191, Warszawa.

Matusiak, K.B., Guliński, J. (red.) (2010). System transferu technologii i komercjalizacji wiedzy w Polsce-sity motoryczne i bariery. Warszawa: Polska Agencja Rozwoju Przedsiębiorczości.

Ministerstwo Gospodarki (2006). Kierunki zwiększania innowacyjności gospodarki na lata 2007-2013. Warszawa.

Ministerstwo Rozwoju Regionalnego (2006). Strategia Rozwoju Kraju 2007-2015. Warszawa, listopad $2006 \mathrm{r}$.

Ministerstwo Rozwoju Regionalnego (2007). Narodowe Strategiczne Ramy Odniesienia 2007-2013 wspierajace wzrost gospodarczy i zatrudnienie. Narodowa Strategia Spójności. Dokument zaakceptowany decyzją Komisji Europejskiej zatwierdzający pewne elementy Narodowych Strategicznych Ram Odniesienia. Warszawa, maj 2007 r.

Ministerstwo Rozwoju Regionalnego (2010). Wpływ funduszy europejskich na gospodarke polskich regionów i konwergencję z krajami UE. Raport 2010. Warszawa.

Molle, W. (2009). European Policies for Innovation and Cohesion; from loose coordination to partial integration. W: Cohesion Policy facing the challenges of the 21st century. Warszawa: Ministerstwo Rozwoju Regionalnego.

Molle, W. (2011). European economic governance. The quest for consistency and effectiveness. Routledge Studies in the European Economy. London-New York: Routledge.

Murzyn, D. (2012). Udział małopolskich przedsiębiorstw w polityce regionalnej Unii Europejskiej. Zarzadzanie i Finanse. Journal of Management and Finance, Vol. 10, No. 1, Part 2. Wydział Zarządzania Uniwersytetu Gdańskiego. 
Nelson, R. (red.) (1993). National Systems of Innovation: a comparative study. New York-Oxford: Oxford University Press.

Polska Agencja Rozwoju Przedsiębiorczości (2010). Innowacyjność 2010, Raport przygotowany pod kierunkiem A. Wilmańskiej. Warszawa.

Polska Agencja Rozwoju Przedsiębiorczości (2011). Raport o stanie sektora matych i średnich przedsiębiorstw w Polsce. Warszawa.

Verspagen, B. (1994). Technology and growth: complex dynamics of convergence and divergence. W: G. Silverberg, L. Soete, The economics of growth and technical change. Technologies, nations, agents. Aldershot: Edward Elgar Publishing Company.

Wintjes, R., Hollanders, H. (2010). The regional impact of technological change in 2020, UNU-MERIT.

Dorota Murzyn, dr, Uniwersytet Pedagogiczny w Krakowie.

Doktor nauk humanistycznych w zakresie nauk o polityce, magister ekonomii, adiunkt w Instytucie Politologii Uniwersytetu Pedagogicznego w Krakowie (Katedra Ekonomii i Polityki Gospodarczej). Zainteresowania badawcze autorki to polityka gospodarcza, integracja europejska, polityka spójności UE. Członek Regional Studies Association, Seaford, UK.

Dorota Murzyn, Ph.D. in Political Science, MA in Economics, Senior Lecturer at the Institute of Political Science, Pedagogical University of Cracow (Department of Economics and Economic Policy). Her research interests are: economic policy, European integration, EU cohesion policy. Member of Regional Studies Association, Seaford, UK.

adres/address: Uniwersytet Pedagogiczny w Krakowie ul. Podchorążych 2, pok. 224, 30-084 Kraków, Polska

e-mail:mdorota@up.krakow.pl 